\title{
Ophthalmological profile of patients with thyroid diseases in Fortaleza, Ceará, Brazil: glaucoma investigation
}

\section{Perfil oftalmológico de pacientes com tireoidopatias em Fortaleza, Ceará, Brasil: investigação de glaucoma}

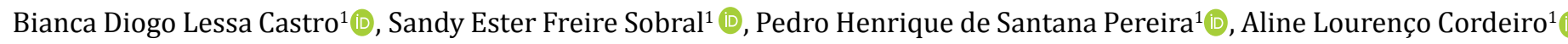 \\ Sarah Dibe Santos ${ }^{1}$ (D) , Ana Adélia Sá Costa ${ }^{1}$ (D) , Herculano Pontes Barros Ribeiro ${ }^{1}$ (D), Hissa Tavares de Lima Gradvohl ${ }^{3}$ (D), Laura \\ da Silva Girão Lopes² ${ }^{2}$, Juliana de Lucena Martins Ferreira ${ }^{2,3}$ (C)
}

1. Medicine Student, Centro Universitário Christus (Unichristus), Fortaleza, CE, Brasil. 2. Clínica Escola de Saúde, Centro Universitário Christus (CES/ Unichristus), Fortaleza, CE, Brasil. 3. Fundação Leiria de Andrade (FLA), Fortaleza, CE, Brasil.

\begin{abstract}
Objective: To evaluate the prevalence of ophthalmological pathologies, between thyroidopathies, for early diagnosis of glaucoma in patients seen at the Clínica Escola de Saúde (CES) of the Medicine Center of the Centro Universitário Christus (UNICHRISTUS), Fortaleza - Ceará - Brazil. Methods: A cross-sectional study and descriptive analysis of medical records of patients diagnosed with hypothyroidism or hyperthyroidism by the International Classification of Diseases (ICD-10) on the CES electronic system, between 2013 and 2018. Screened patients were invited to perform an eye examination at Fundação Leiria de Andrade (FLA). Results: Of the 499 medical records screened, 22.8\% (114) had a confirmed diagnosis for thyroid disorders, 85.9\% (98) with hypothyroidism, and $14.0 \%$ (16) with hyperthyroidism. Of these, $72.0 \%$ (101) were women and $28.0 \%$ (13) men. The most prevalent age group was between 41 and 60 years old, corresponding to 46.4\% (53), being 65.7\% (75) from Fortaleza - Ceará. The main comorbidities associated with thyroid diseases were systemic arterial hypertension, 43.8\% (50), followed by dyslipidemia, 26.3\% (30), and type 2 diabetes mellitus in 13.1\% of patients (15). Of the total, 25 patients were referred to the FLA, 84.0\% (21) reported previous eye diseases, $4.0 \%$ (1) diagnosticated with increased constitutional excavation, and $12.0 \%$ (3) with a diagnosis of primary open-angle glaucoma. Conclusion: Despite the hypothesis of an association between glaucoma and thyroidopathy, the sample size didn't allow inferences about the increased risk of its correlation, as well as in other pre-existing studies in the literature, requiring further studies to elucidate this relevant association.
\end{abstract}

Keywords: Glaucoma; Thyroid; Hypothyroidism; Hyperthyroidism; Intraocular Pressure.

\section{Resumo}

Objetivo: avaliar a prevalência de glaucoma entre os portadores de patologias tireoidianas, acompanhados na Clínica Escola de Saúde (CES) do núcleo de Medicina do Centro Universitário Christus (UNICHRISTUS), Fortaleza - Ceará - Brazil. Métodos: estudo transversal e descritivo de prontuários de pacientes diagnosticados com hipotireoidismo ou hipertiroidismo pelo Código Internacional de Doenças (CID-10) no sistema eletrônico da CES, entre 2013 e 2018. Pacientes triados foram convidados a realizar um exame oftalmológico na Fundação Leiria de Andrade (FLA). Resultados: dos 499 prontuários triados, 22,8\% (114) possuíam diagnóstico confirmado para tireoidopatias, sendo 85,9\% (98) com hipotireoidismo, e 14,0\% (16) com hipertireoidismo. Desses, $72,0 \%$ (101) eram mulheres e $28,0 \%$ (13) homens. A faixa etária mais prevalente foi entre 41 a 60 anos de idade, correspondendo a 46,4\% (53), sendo $65,7 \%$ (75) de Fortaleza - Ceará - Brasil. As principais comorbidades associadas às tireoidopatias foram hipertensão arterial sistêmica, representando $43,8 \%$ (50), seguida de dislipidemia, 26,3\% (30) e diabetes mellitus tipo 2 em 13,1\% dos pacientes (15). Do total, 25 pacientes foram encaminhados à FLA, 84,0\% (21) relataram doenças oculares prévias, 4,0\% (1) diagnosticado com escavação aumentada constitucional e 12,0\% (3) com diagnóstico de glaucoma primário de ângulo aberto. Conclusão: apesar da hipótese de associação entre o glaucoma e as tireoidopatias, o tamanho amostral não possibilitou inferências sobre o risco aumentado de sua correlação, assim como em outros estudos preexistentes na literatura, sendo necessários mais estudos para elucidar com maior precisão essa associação relevante.

Palavras-chave: Glaucoma; Tireoide; Hipotireoidismo; Hipertireoidismo; Pressão Intraocular.

\section{INTRODUCTION}

Hypothyroidism is a dysfunction of the thyroid gland resulting from the reduction in the action of its hormones in the various systems. It affects approximately $10 \%$ of the world population, being more prevalent at increasing ages. The symptoms of this condition include fatigue, drowsiness, weight gain, feeling cold, weakness, hair loss, dry skin, depression, changes in memory and concentration, slow muscle contraction, myxedema, constipation, and irregular menstrual cycles..$^{1-3}$ Hyperthyroidism, in turn, results from the excess of thyroid hormones in the bloodstream. It has a prevalence of 0.3 to $1.0 \%$ in the general population, and $2.0 \%$ in the elderly, and its clinical manifestations are diverse and include: tachycardia, hair loss, weight loss, insomnia, anxiety, exophthalmos, among others. $^{4}$

Glaucoma is considered by the World Health Organization (WHO) to be the biggest cause of irreversible blindness. Conceptually, it is progressive optic neuropathy, with mostly

Correspondence: Bianca Diogo Lessa Castro. Rua Carlota Pinheiro, no 255 - apto 1001 B. 60810019 - Fortaleza (CE), Brasil. E-mail: biancalessac@hotmail. com 
silent behavior, which evolves with the destruction of the retinal ganglion cells. Upon examination, mostly, the diagnosis can be suspected by perceiving an increased excavation of the optic nerve or elevation of intraocular pressure (IOP). It is a more evident condition in people of advanced age, positive family history, and black ethnicity. Symptoms only manifest in more advanced stages, leading many patients to seek medical attention in late stages, with severe visual impairment. ${ }^{5,6}$

The association between thyroid disorders and glaucoma has already been highlighted by some researchers, but it is still considered imprecise, as some show a positive correlation, and others do not. ${ }^{1,7-9}$ Therefore, deepening around these pathologies would help the early diagnosis of glaucoma in patients with thyroid dysfunction, thus preventing the evolution to permanent vision loss. ${ }^{10-12}$

\section{METHODS}

It was a cross-sectional study, with retrospective and descriptive analysis of medical records contained in the computerized system of the Clínica Escola de Saúde (CES) belonging to the Medicine Center of the Centro Universitário Christus (UNICHRISTUS), in Fortaleza - Ceará - Brazil. The participants were diagnosed with hypothyroidism or hyperthyroidism by the International Classification of Diseases (ICD-10) registered in CES 'electronic system.

The medical records with the ICD-10 were included in the study based on evidence of clinical and / or laboratory confirmation of thyroid disease, from 2013 to 2018, and which had the following information: sex, age, telephone number for contact, origin, and place of birth, year diagnosis, follow-up time, etiology of hyperthyroidism or hypothyroidism, comorbidities and medications in use at the time of collection.

The screened patients were approached, by telephone, and invited to participate in the research, performing an eye examination at the Leiria de Andrade Foundation (FLA) for the diagnosis of glaucoma (including visual acuity, biomicroscopy, Goldman's applanation tonometry, gonioscopy, and fundoscopy). Suspected cases were confirmed by carrying out complementary tests, such as color retinography (Digital retinal camera $\mathrm{CX}-1$, Canon, Inc), computerized campimetry (Humphrey Field Analyzer SITA-FAST 24-2, Carl Zeiss Meditec, Inc), by simplified Hodapp-Parrish-Anderson criteria, and optical coherence tomography (Cirrus HD-OCT, software version 3.0, Carl Zeiss Meditec, Inc.) for evaluation of the nerve, peripapillary and macular region.30

The collected data were described using usual parameters of descriptive statistics, by means of frequency and average, using Microsoft Excel ${ }^{\circledR} 2010$ software.

The research followed the principles outlined in the Declaration of Helsinki, which was previously approved by the Research Ethics Committee under the numbers CAAE: 88276418.1.0000.5049 and 88875518.4.0000.5049.

\section{RESULTS}

Initially, 499 medical records were screened, however, only $22.8 \%(n=114)$ had a confirmed diagnosis for thyroid disorders, $85.9 \%(n=98)$ with hypothyroidism and $14.0 \%(n=16)$ with hyperthyroidism. Of the selected individuals, $88.5 \%(n=101)$ were female and $11.4 \%(n=13)$ male. Regarding the age group, $26.3 \%(n=30)$ were between 20 and 40 years old, $46.4 \%$ ( $n$ $=53$ ) between 41 and 60 years old, $25.4 \%(n=29)$ between 71 and 80 years old and $1.7 \%(n=2)$ were over 80 years old. Regarding the origin of the patients, $65.7 \%(n=75)$ were from Fortaleza - Ceará, $19.2 \%(n=22)$ from the interior of the State and $14.9 \%(n=17)$ did not present the origin registered in the medical record.

The symptoms of hypothyroidism or hyperthyroidism described in the medical records are shown in Table 1. Among the comorbidities associated with thyroid diseases, 43.8\% ( $n=50)$ had systemic arterial hypertension (SAH), $13.1 \%(n=15)$ type 2 diabetes mellitus (T2D), 26.3\% ( $n=30)$ dyslipidemia and $19.2 \%(n=22)$ had other, less prevalent comorbidities, namely: osteoporosis $(n=5)$, anxiety disorder $(n=5)$, depression $(n=3)$, hyperparathyroidism $(n=3)$, polycystic ovary syndrome $(n=3)$, labyrinthitis $(n=2)$, breast cancer $(n=2)$, migraine $(n=2)$, obesity $(n=2)$, bipolar disorder $(n=1)$, idiopathic thrombocytopenic purpura $(n=1)$, metabolic syndrome $(n=1)$, osteoarthritis ( $n$ $=1)$, ocular toxoplasmosis $(n=1)$, asthma $(n=1)$, fibromyalgia $(n=1)$, hepatic steatosis $(n=1)$, biliary lithiasis $(n=1)$ chronic kidney disease $(n=1)$, gastric cancer $(n=1)$, heart failure $(n=1)$ and gastroesophageal reflux disease $(n=1)$.

Table 1. Clinical manifestations, according to each system, in thyroid patients $(n=114)$. Some patients presented more than one affected system.

\begin{tabular}{lrr}
\hline Affected Systems & Absolut number (n) & Percentage (\%) \\
\hline Cardiovascular system & 35 & 30.7 \\
Integumentary system & 39 & 34.2 \\
Digestive system & 34 & 29.8 \\
Musculoskeletal system & 35 & 30.7 \\
Hematological system & 15 & 13.1 \\
Neuropsychiatric system & 59 & 51.7 \\
Metabolic system & 40 & 35.0 \\
Reproductive system & 16 & 14.0 \\
Respiratory system & 6 & 5.2 \\
\hline
\end{tabular}

About the drugs used, $63.1 \%(n=72)$ used levothyroxine, $7.0 \%$ $(n=8)$ tapazole, $0.9 \%(n=1)$ propylthiouracil, $4.3 \%(n=5)$ propranol, 9.6\% $(n=11)$ atenolol, $19.2 \%(n=22)$ simvastatin, $21.0 \%(n=24)$ losartan, $11.4 \%(n=13)$ metformin and $0.9 \%(n$ $=1$ ) insulin.

Of the 114 medical records selected, the vast majority had an invalid telephone number or did not answer the call, some refused with the justification of living in distant and difficult 
to access places, mainly in the interior of the state, or due to difficulties in accessing transportation to the hospital service location. Thus, resulting in only 25 patients (50 eyes) submitted to ophthalmological evaluation at the FLA. Of these patients, $72.0 \%$ ( $n=18$ ) were female and $28.0 \%(n=7)$ were male. Regarding the age of these patients, $12.0 \%(n=3)$ were 20 to 40 years old, $56.0 \%(n=14)$ were 41 to 60 years old, $28.0 \%(n=7)$ were 61 to 80 years old and $4.0 \%(n=1)$ over 80 years old. The systemic comorbidities present among these 25 patients were: T2D $(n=6)$, SAH $(n=12)$, and five were also accompanied by thyroid nodules. Regarding the ophthalmological history, $96.0 \%$ $(n=24)$ reported previous eye diseases (Table 2$), 24.0 \%(n=6)$ had already undergone ophthalmologic surgery (four patients underwent cataract excision and two removals of pterygium) and $16.0 \%(n=4)$ had a positive family history for glaucoma.

Table 2. History of previous eye diseases in thyroid patients ( $n=$ 25). Some patients presented more than one ocular antecedent.

\begin{tabular}{lrr}
\hline Ocular antecedents & Absolute number $(\mathbf{n})$ & Percentage $(\%)$ \\
\hline Astigmatism & 14 & 36.8 \\
Hyperopia & 10 & 26.3 \\
Myopia & 4 & 10.5 \\
Cataract & 3 & 7.8 \\
Glaucoma & 1 & 2.6 \\
Denied & 6 & 15.7 \\
\hline
\end{tabular}

The ophthalmological evaluation found five patients (a total of 10 eyes, that is, $20.0 \%$ of the sample) with suspected glaucoma and diagnostic confirmation with complementary functional and structural exams detected three eyes with primary open angle glaucoma (POAG) in moderate stage and one eye with POAG in its initial stage, with six eyes with constitutional augmented excavation (CAE) without signs of glaucoma. The detailed result of the changes found in the eye examination is shown in Table 3.

Table 3. Ocular changes on eye examination of thyroid diseases patients $(n=50)$. Some individuals presented more than one ocular alteration.

\begin{tabular}{lrr}
\hline Alterations & Absolut number $(\mathbf{n})$ & Percentage (\%) \\
\hline LVA (<0.5) & 3 & 6.0 \\
Astigmatism & 14 & 28.0 \\
Hyperopia & 10 & 20.0 \\
Myopia & 4 & 8.0 \\
Dermatochalasis & 4 & 8.0 \\
Pterygium & 8 & 16.0 \\
Cataract & 3 & 6.0 \\
POAG & 4 & 8.0 \\
CAE & 6 & 12.0 \\
\hline Legend: *LVA (low visual acuity), according to the decimal scale of the Snellen \\
table; CAE (constitutional augmented excavation); POAG (primary open-angle \\
glaucoma) & \multicolumn{2}{l}{}
\end{tabular}

\section{DISCUSSION}

The present result demonstrated the highest prevalence of thyroid disease in females and the age group 41 to 60 years, corroborating with the literature, ${ }^{13}, 14$ however, some studies have presented divergent results in relation to age, with greater involvement in individuals of the third age (over 65) when it comes to hypothyroidism. ${ }^{15,16}$ Also, the notorious use of levothyroxine was observed by $63.1 \%$, more than half of the patients, which was expected in a group of patients with thyroid disorders, as stated in an Italian paper, in 2019, which showed, in addition, a low adherence rate between 20.0 to $30.0 \%$ of patients, when compared to other drugs prescribed, such as proton pump inhibitors, and a portion of 30.0 to $40.0 \%$ of patients who even using hormone replacement, continued with symptoms of hypothyroidism, requiring combined replacement therapy, which is interesting data for future studies. ${ }^{22}$ Associated with this, this study also showed the care that should be taken with patients with other comorbidities, drawing more attention to SAH, T2D, how should this drug association be made, a fact that was reinforced in the results of the current study, informing which drugs the patients were using, mainly for arterial pressure control, like atenolol by $19.2 \%$ of the patients, and lipid profile, simvastatin by $21.0 \%$ of the sample, was relevant when compared to the other drugs used.

Bearing in mind that the thyroid is the largest gland in the human body, the world literature emphasizes that problems in its functioning can generate cardiovascular, metabolic, bone, and mental health changes, ${ }^{1-3,14,17-18}$ corroborating with the present study that found several associated comorbidities, such as $43.8 \%$ of $\mathrm{SAH}, 13.1 \%$ of T2D, $26.3 \%$ of dyslipidemia and $19.2 \%$ of other diseases (osteoporosis, anxiety disorder, depression, hyperparathyroidism, polycystic ovary syndrome, labyrinthitis, cancer of breast, migraine, obesity, bipolar disorder, idiopathic thrombocytopenic purpura, metabolic syndrome, osteoarthritis, ocular toxoplasmosis, asthma, fibromyalgia, hepatic steatosis, biliary lithiasis, chronic kidney disease, gastric cancer, heart failure, and gastroesophageal reflux disease).

Glaucoma is optic neuropathy, which has as its main risk factor the increase in IOP, due, for example, to increased production and deposition of mucopolysaccharides in the trabecular meshwork, which reduces the output of aqueous and increases IOP, which is one of the hypotheses that associate hypothyroidism with glaucoma., ${ }^{3,19-20}$ The association can also come from the inflammatory process involved in orbitopathy that causes the exophthalmos present in hyperthyroidism, which can cause an increase in IOP and cause more severe consequences, such as loss of vision due to glaucoma. 10 This reinforces the importance of the current study for surveillance of these pathologies and their consequences for the population.

The present study had some limitations like only $22.8 \%$ of the medical records had complete data with the diagnostic confirmation of thyroid disease; of these, only 25 patients participated in the eye examination, as the others had an invalid 
phone number or did not answer the phone call or refused to participate. Therefore, the sample size studied (50 eyes) was not sufficient to conclude the existence of a significant association between thyroid disorders and glaucoma. However, the epidemiological and clinical evaluation of this sample (114 patients) deserves to be highlighted because it comes from a region where there is no previous published data evolving glaucoma and thyroid diseases, diseases that are very prevalent in clinical practice. Brazilian studies, for the most part, use the Longitudinal Study of Adult Health (ELSA Brazil) for their data collections, due to the scarcity of other works related to this subject, such as Olmos et al., in 2015, making associations between social and racial factors with thyroid disorders, and the study by Jancovysky, Bittencourt, and Goullar, in 2019, which was to look for the prevalence of anti-peroxidase antibody in the Brazilian population, seeing that its relationship with the disease has not yet been established. ${ }^{23-24}$ The knowledge gap regarding the association of these morbidities persists, and future studies are necessary to obtain more significant conclusions.

The patients evaluated by an ophthalmologist, already in clinical history, it was possible to identify risk factors for glaucoma, such as age over 40 years (88.0\% of the sample examined), which is expected, considering a series of studies showing a prevalence of $2.0-3.0 \%$ in the population over 40 years, with a dramatic increase in prevalence with age, mainly in Latinos and Spaniards. According to Baltimore Eye Study, the prevalence of glaucoma increases by $5.0 \%$ every decade, starting at age $40 .{ }^{16,25}$

It was also possible to verify the presence of family history for this pathology (but in only $16.0 \%$ of the interviewees). In this regard, it is worth mentioning that some studies strongly refer to the prevalence of glaucoma considering this variable. According to the Rotterdam Eye Study, the chance of a person developing glaucoma, having a brother with the same pathology, is 9.2 times higher than the general population. However, most cases are not strictly related to genetic conditions, and the multifactorial causality of glaucomatous damage can once again be inferred. ${ }^{16,25}$

In the 1920s, scholars speculated that hypothyroidism was an important risk factor for the development of glaucoma. They suggested that the low metabolic condition, caused by hypothyroidism, would lead to a decrease in enzyme activities that would affect the dynamics of aqueous humor. There are theses that maintain that one of the possible mechanisms that support this susceptibility and progression of glaucoma in hypothyroid patients is the deposition of mucopolysaccharides and hyaluronic acid in the trabecular meshwork, which, in turn, would obstruct the outflow of aqueous humor, increasing IOP. Another potential event would be an increase in resistance to outflow in these patients. This was demonstrated by Sten et al. in analysis through subconjunctival injection of hyaluronidase in normal people and with glaucoma, where it was seen that resistance to outflow was significantly greater in glaucoma patients. ${ }^{3,26-27}$

One meta-analysis carried out with 11 studies, with a sample of 381,695 people, demonstrated a statistically significant association, in which individuals with hypothyroidism were 1.64 times more likely to develop POAG than the population without the pathology. However, it is worth mentioning that such results are conflicting in the current literature in some analyzes of cross-sectional studies, which do not show such an association, which can be explained, perhaps, by the selection bias to which this study model is submitted. ${ }^{3,26}$

Despite the divergences, some articles have demonstrated a correlation between the development of glaucoma in patients with hyperthyroidism. The main hypothesis for this finding considers the deposition of anti-thyroglobulin immune complexes in the extraocular muscles, which induce an inflammatory response, resulting in edema and fibrosis. Exophthalmos, resulting from this process, can increase IOP, causing damage to episcleral venous drainage, with the possible consequent progression of glaucomatous damage. ${ }^{28-29}$

The present study found a higher prevalence of POAG $(8.0 \%$ of the sample analyzed, against zero other types of glaucoma) among thyroid patients. However, there is still a need to continue investigating the possible mechanisms that exist in this possible relationship and its development, in order to determine whether thyroid disorders instigate and / or aggravate glaucomatous damage. Experimental studies are also suggested to better understand this correlation, which is still not as well elucidated in the literature.

Although the hypothesis of an association between glaucoma and thyroid disorders has been raised, the sample size of the study did not allow inferences about the increased risk of correlation between these pathologies. However, it was emphasized the clinical and epidemiological data of these patients, which are relevant because it is a study that has been little addressed in the region. Thus, further studies are needed involving larger samples and with more clinical and laboratory data, since there was a shortage of them in the medical records accessed, restricting the scope of the research.

\section{REFERENCES}

1. Lee AJ, Rochtchina E, Wang JJ, Healey PR, Mitchell P. Open-angle glaucoma and systemic thyroid disease in an older population: The Blue Mountains Eye Study. Eye (Lond). 2004 Jan;18(6): 600-608.

2. Guyton AC, Hall JE. Tratado de Fisiología Médica. 13. ed. Madrid: Elsevier; 2017.
3. Wang S, Liu Y, Zheng G. Hypothyroidism as a risk factor for open angle glaucoma: A systematic review and meta-analysis. PLoS One. 2017 Oct;12(10): e0186634. doi: 10.1371/journal.pone.0186634.

4. Gadelha P, Montenegro RM. Interpretação dos Testes de Função da Tireóide. In: Lucio V. Endocrinologia Clínica. 6. ed. Rio de Janeiro: Guanabara Koogan; 
2016.

5. Demarco AL, Rodrigues M de L, Demarco LA. Perfil oftalmológico de pacientes ingressantes no setor de glaucoma de um serviço universitário. Medicina. 2002; 35(4): 478-86

6. Quigley HA, Broman AT. The number of people with glaucoma worldwide in 2010 and 2020. Br J Ophthalmol. 2006 Mar; 90(3): 262-267. doi: 10.1136/ bjo.2005.081224.

7. Ajith TA, Ranimenon. Association of hypothyroidism with glaucoma: a recent update. ARC J Ophthalmol. 2016; 1(1): 23-27.

8. Motsko SP, Jones JK. Is there an association between hypothyroidism and open-angle glaucoma in an elderly population? An epidemiologic study. Ophthalmology. 2008 Sep; 115(9): 1581-1584. doi: 10.1016/j. ophtha.2008.01.016.

9. Tahat AA, al-Khawaldeh AM. Hypothyroidism and open-angle glaucoma: na accidental or an essential coexistence? East Mediterr Health J. 2000 Mar-May; 6(2-3): 299-303.

10. Lewis, S., Heitkemper, M., Dirksen, S. and Bucher, L. Problemas Visuais e Auditivos. In: Tratado De Enfermagem Médico-Cirúrgica. 8 ed. Rio de Janeiro: Elsevier; 2013

11. Ramalho CM, Ribeiro LN, Olivieri LS, Silva JA, Vale TC, Duque WP. Perfil socioeconômico dos portadores de glaucoma no serviço de oftalmologia do hospital universitário da Universidade Federal de Juiz de Fora - Minas Gerais - Brasil. Arq. Bras. Oftalmol. 2007 Oct; 70(5): 809-813. doi: https://doi. org/10.1590/S0004-27492007000500015.

12. Tavares IM, Mello PAA. Glaucoma de pressão normal. Arq. Bras. Oftalmol. 2005 Ago; 68(4): 565-575. doi: https://doi.org/10.1590/S000427492005000400028

13. Darouassi Y, Hanine MA, Aljalil A, Ennouali A, Bouaity B, Touati MM, Ammar H. Chirurgie des hyperthyroïdies: à propos de 60 cas. Pan Afr Med J. 2018 20 31: 43. doi: 10.11604/pamj.2018.31.43.16695

14. Taylor PN, Albrecht D, Scholz A, Gutierrez-Buey G, Lazarus JH, Dayan CM, Okosieme OE. Global epidemiology of hyperthyroidism and hypothyroidism. Rev Endocrinol. 2018 Mar; 14(5): 301-316.

15. Bornschein A, Paz G, Graf H, Carvalho GA. Tratamento do hipotireoidismo primário com doses semanais de levotiroxina: um estudo randomizado, cego e cruzado. Arq Bras Endocrinol Metab. 2012 Jun; 56(4):250-258. doi: https://doi. org/10.1590/S0004-27302012000400006.

16. Brasil, Ministério da Saúde. Protocolo Clínico e Diretrizes Terapêuticas Glaucoma. Brasília, 2018. Disponível em: http://conitec.gov.br/images/ Relatorios/2018/Relatorio_PCDT_Glaucoma.pdf.

17. Miranda EJP. Associação entre doença tireoidiana subclínica, aterosclerose coronariana, índice de espessura de médio-íntima carotídea e rigidez arterial aórtica em análise transversal do Estudo Longitudinal de Saúde do Adulto (ELSA-Brasil) [tese]. São Paulo (SP): Faculdade de Medicina; 2017.
18. Ochs N, Auer R, Bauer DC, Nanchen D, Gussekloo J, Cornuz J, Rodondi N. Meta-analysis: subclinical thyroid dysfunction and the risk for coronary heart disease and mortality. Ann Intern Med. 2008 Jun;148(11): 832-845. doi: 10.7326/0003-4819-148-11-200806030-00225.

19. Gillow JT, Shah P, O'Neill EC. Primary open angle glaucoma and hypothyroidism: chance or true association? Eye (Lond). 1997; 11(Pt 1):113114. doi: 10.1038/eye.1997.22.

20. Lin HC, Kang JH, Jiang YD, Ho JD. Hypothyroidism and the risk of developing open-angle glaucoma: a five-year population-based followup study. Ophthalmology. 2010 Oct; 117(10): 1960-1966. doi: 10.1016/j. ophtha.2010.02.005

21. Leske MC, Connell AM, Schachat AP, Hyman L. The Barbados Eye Study Prevalence of open angle glaucoma. Arch Ophthalmol. 1994 Jun; 112(6): 821829. doi: 10.1001/archopht.1994.01090180121046.

22. Biondi B, Cooper DS. Thyroid hormone therapy for hypothyroidism. Endocrine. 2019 Oct; 66(1): 18-26. doi:10.1007/s12020-019-02023-7.

23. Janovsky CCPS, Bittencourt MS, Goulart AC, et al. Prevalence of antithyroperoxidase antibodies in a multiethnic Brazilian population: The ELSABrasil Study. Arch Endocrinol Metab. 2019; 63(4): 351-357. doi:10.20945/23593997000000122

24. Olmos, R. D., de Figueiredo, R. C., Aquino, E. M., Lotufo, P. A., \& Bensenor, I. M. (2015). Gender, race and socioeconomic influence on diagnosis and treatment of thyroid disorders in the Brazilian Longitudinal Study of Adult Health (ELSA-Brasil). Braz J Med Biol Res. 2015 Aug; 48(8): 751-758. doi: https:// doi.org/10.1590/1414-431X20154445.

25. Tielsch JM, Sommer A, Katz J, et al. Racial variations in the prevalence of primary open-angle glaucoma: The Baltimore Eye Survey. JAMA 1991 Jul; 266(3): 369-74.

26. Smith KD, Tevaarwerk GJ, Allen LH. An ocular dynamic study supporting the hypothesis that hypothyroidism is a treatable cause of secondary open-angle glaucoma. Can J Ophthalmol. 1992 Dec; 27(7): 341-344.

27. Stein R, Romano A, Treister G, Bartov E (1982) Effect of subconjunctival injection of hyaluronidase on outflow resistance in normal and in open-angle glaucomatous patients. Metab Pediatr Syst Ophthalmol. 1982; 6(3-4): 169-174

28. Lima WTA, Perches M, Valera FCP, et al. Descompressão endoscópica orbitária na oftalmopatia de Graves. Rev Bras Otorrinolaringol. 2006; 72(2):283287.

29. Bueno MAC, Guidi MC, Oliveira LM, et al. Oftalmopatia na doença de Graves: revisão da literatura e correção de deformidade iatrogênica. Rev Bras Cir Plást 2008; 23(3): 220-225.

30. Gupta N, Aung T, Congdon N, Dada T, Lerner F, Olawaye S et al. Diretrizes do ICO para tratamento do glaucoma. California: Conselho Internacional de Oftalmologia; 2015. 27p.

\section{How to cite this article/Como citar este artigo:}

Castro BDL, Sobral SEF, Pereira PHS, Cordeiro AL, Santos SD, Costa AAS, et al. Ophthalmological profile of patients with thyroid diseases in Fortaleza, Ceará, Brazil: glaucoma investigation. J Health Biol Sci. 2021; 9(1):1-5. 